\section{Identifying the diversity of self-sown native coconuts (Cocos nucifera L.) and the introduced phenotype in Queensland, Australia}

\author{
André Leu \\ International Director, Regeneration \\ International, Australia
}

\begin{abstract}
The claims that all coconuts (Coco Nucifera L.) were introduced into Australia by Europeans were researched by studying the journals of the maritime expeditions, the records of the Queensland Acclimatisation Society, historical data and published papers. The 1869 minutes of the Queensland Acclimatisation Society stated that no introduced coconuts were fruiting, and the Queensland Governor stated that there were self-sown coconut palms on the coast. A large spherical niu vai phenotype was introduced from the 1870 s to 1900 . Field research was conducted in the vicinity of an historical coconut plantation at Wonga Beach. Nuts and palms were examined to understand if all coconuts in that region were descended from the introduced phenotype. Most self-sown coconuts are intermediate types with native Australian origins, not the introduced phenotype.
\end{abstract}

\section{Introduction}

There is a widespread belief that the coconut (Cocos nucifera L.) is not native to Australia and that it was introduced by Europeans. ${ }^{1-4}$ The reasons given are that there were no Aboriginal words for coconuts, the first European mariners did not find wild coconut palms and they planted coconuts.

A search of dictionaries, historical and other papers show that numerous traditional owners had multiple words for coconuts, specific names for groves, stated that coconuts have always been in Australia, owned trees, and used them for food, artifacts and ceremonies. The indigenous knowledge, linguistics and oral history about coconuts is evidence that they grew in Australia prior to European colonization in $1788 .^{5}$

A search of the reports of the early European mariners shows that they regularly found evidence of coconuts including green and fresh nuts. Mature coconut palms were found from 1848 onwards. ${ }^{5}$

Research into the evolution of coconuts shows that their predecessors originated from the time when South America, Africa, India, Australia, New Zealand and Antartica were joined as the super continent of Gondwana. Fossils of related species have been found in Colombia, India and New Zealand. ${ }^{2,6}$ The only fossil of Cocos nucifera L. was found in Australia. ${ }^{1,7,8}$ Based on the current fossil evidence it is possible that the coconut evolved in Australia and then spread throughout the Indo-Pacific (Figure $1)$.

\section{Methodology}

The claims that all coconuts in Australia were introduced were researched by studying the journals of the maritime expeditions and records of the Queensland Acclimatisation Society, the official organization that introduced coconuts. A range of published historical data, research theses and published papers were searched to find evidence. The scope of this research was restricted to tropical eastern Queensland as this region of Australia has the climate zone most suitable for self-sown coconuts to grow and fruit. The rest of Australia is mostly too cold or too dry for self-sown coconuts, apart from a few micro-climates. ${ }^{2}$ The scope was also restricted to self-sown plants on the littoral foreshore as this is the ecological niche of coconuts. Wild coconuts are spread by sea drift and self-sow above the strand line. They have no natural mechanism to spread inland as the nuts can't roll up hill by themselves. Coconuts growing further inland have been planted by people. ${ }^{2}$ Field research was conducted in the vicinity of an historical coconut plantation at Wonga Beach (16.35 S). Nuts and palms were examined to understand if all self-sown coconuts in that region were the introduced phenotype.

\section{Researching the introduction of coconuts}

The journals of the maritime exploration expeditions up to 1848 , when selfsown coconuts were found on Russell Island, do not mention planting coconuts or having coconuts on board their ships, even though they mention planting other species. Apart from two occasions, I have been unable to find records of ships stopping to plant coconuts prior to the 1890 s. These are: Cunningham, the naturalist on King's surveys, planted a fresh coconut on North Goulburn Island that he found on the beach at South Goulburn Island in the Northern
Correspondence: André Leu, PO Box 800, Mossman, Queensland, Australia.

Tel.: +61428459870

E-mail: andreleu.al@gmail.com

Key words: Cocos nucifera L., native Australian coconuts, niu vai, niu kafa.

Conflict of interest: The author declares no conflict of interest

Funding: None

Received for publication: 18 April 2021.

Revision received: 9 May 2021.

Accepted for publication: 12 May 2021.

This work is licensed under a Creative Commons Attribution-NonCommercial 4.0 International License (CC BY-NC 4.0).

${ }^{C}$ Copyright: the Author(s), 2021

Licensee PAGEPress srl, Italy

International Journal of Plant Biology 2021; $12: 9192$ doi:10.4081/pb.2021.9192

Territory in 1818 and Hill, the Queensland colonial botanist, planted native coconuts on the coast that he collected from Russell Island in $1873 .^{9-11}$

The early expeditions in Queensland were mostly charting the inner section Great Barrier Reef, to map the reefs to prevent shipwrecks. Numerous ships were wrecked, especially when they entered the northern section of the Great Barrier Reef to sail through the Torres Straits. Consequently, most merchant and navy ships of that period sailed outside the Great Barrier Reef and did not venture near the reef edge, islands or coast to avoid being shipwrecked. ${ }^{9,10,12}$

Coconuts were regularly imported into Australia from the early 1800 s onwards for food and oil. These cargos of nuts are sometimes cited as proof of their widespread introduction. The records of the Queensland Acclimatisation Society show coconuts were planted in temperate regions of New South Wales and Queensland. Most of these areas are too cold for them to fruit. ${ }^{2,13,14}$

Rockhampton, which is on the Tropic of Capricorn, started as a frontier-town in 1858. Thozet collected herbarium specimens from a 60 -year-old coconut palm in 1864 that was found nearby at Carrawal. ${ }^{15,16}$ The tropical Queensland coast was colonized from 1861 to the 1880s. I have not found records of coconuts being planted in these districts before then. The colonists found mature self-sown coconut palms along this coast when they explored it, such as at Somerset 1864, 
Halifax 1868, Herbert River 1871 and Mission Beach 1873.2

The November 1869 minutes of the Queensland Acclimatisation Society stated that the introduction of coconuts into Queensland had not produced any fruiting trees and was a failure. ${ }^{13}$ The meeting proposed to trial how to grow them successfully. Once this was done, they could establish plantations.

The Governor, Colonel Samuel Wensley Blackall, stated at the meeting that there were self-sown coconut trees on the mainland: His Excellency said he understood that in the islands to the north of Queensland the coconut grew as an indigenous plant, and that seeds from the islands had been washed to the mainland, and had grown there. ${ }^{13}$

This means that there is no evidence that any of the introduced coconut trees were bearing nuts in Queensland by the end of 1869 . The mature trees documented up to the 1870 s were indigenous and by definition are native to Australia. ${ }^{5}$

\section{The traditional owners and coconuts}

Several texts acknowledge that coconuts were constantly drifting to Australia. However, they state that the traditional owners ate all the drift nuts and young palms preventing them from growing on the mainland. ${ }^{2,17}$

There is extensive evidence of drift nuts. Most of the early mariners, from Cook in 1770 , reported them. ${ }^{5}$ Bligh found large numbers when he landed on Restoration Island in 1789. He wrote: "Many pieces, of cocoa-nut shells and husk were found about the shore". ${ }^{18}$ The numerous reports of husks, shells and fresh nuts by early mariners show that drift nuts were not rare events. $^{5}$

It is a data free assumption to state that the traditional owners ate all the drift nuts and prevented them from growing. There is a strong body of evidence showing they owned trees and harvested nuts along 1,000 kilometers of coastline in eastern Queensland.

In 1819, King reported finding a green coconut that had been freshly tapped for its milk at Cape Cleveland, near Townsville. It was found in a traditional owner's village. Green nuts quickly go brown, so this was not a drift nut. ${ }^{9,10}$ It came from a nearby tree. The fact that it had been tapped showed that the traditional owners knew about harvesting green nuts, and this is a much more substantial knowledge than just consuming drift nuts. King knew that it had come from a nearby tree however he did not try to find it. ${ }^{5}$

Hynes and Chase recorded that the Temple Bay and Lockhart River traditional owners stated they owned coconut trees. The Temple Bay traditional owners planted the coconuts surplus to the needs of feeding their children above the strand line. ${ }^{19}$ Tucker recorded that the Lockhart River traditional owners harvested the nuts from self-sown trees they owned. ${ }^{20}$

The Hershbergers working in partnership with Kuku Yalanji elders recorded the names of coconut groves on the Bloomfield River and Emmagen Creek that belonged to the traditional owners. ${ }^{21}$

The mature coconut palm at Carrawal, described by Thozet in 1864, was growing in a traditional owner's village. ${ }^{15,16}$

In 1871 Arthur Neame, a pioneer of the Herbert District, found a tall coconut palm on the beach near Lucinda. He wrote that “... it had nearly 100 nuts growing quite high up, I brought down 3 with a shot from my revolver but they were not nearly fit for use, the natives pick them as soon as they can make any use of them." This shows that the traditional owners climbed the palm and harvested green nuts. ${ }^{22}$

Dalrymple found a coconut tree near Mission Beach in 1873. "Inside Tam O'Shanter Point... is a fine young cocoanut

\section{The introduction of coconuts to Queensland}

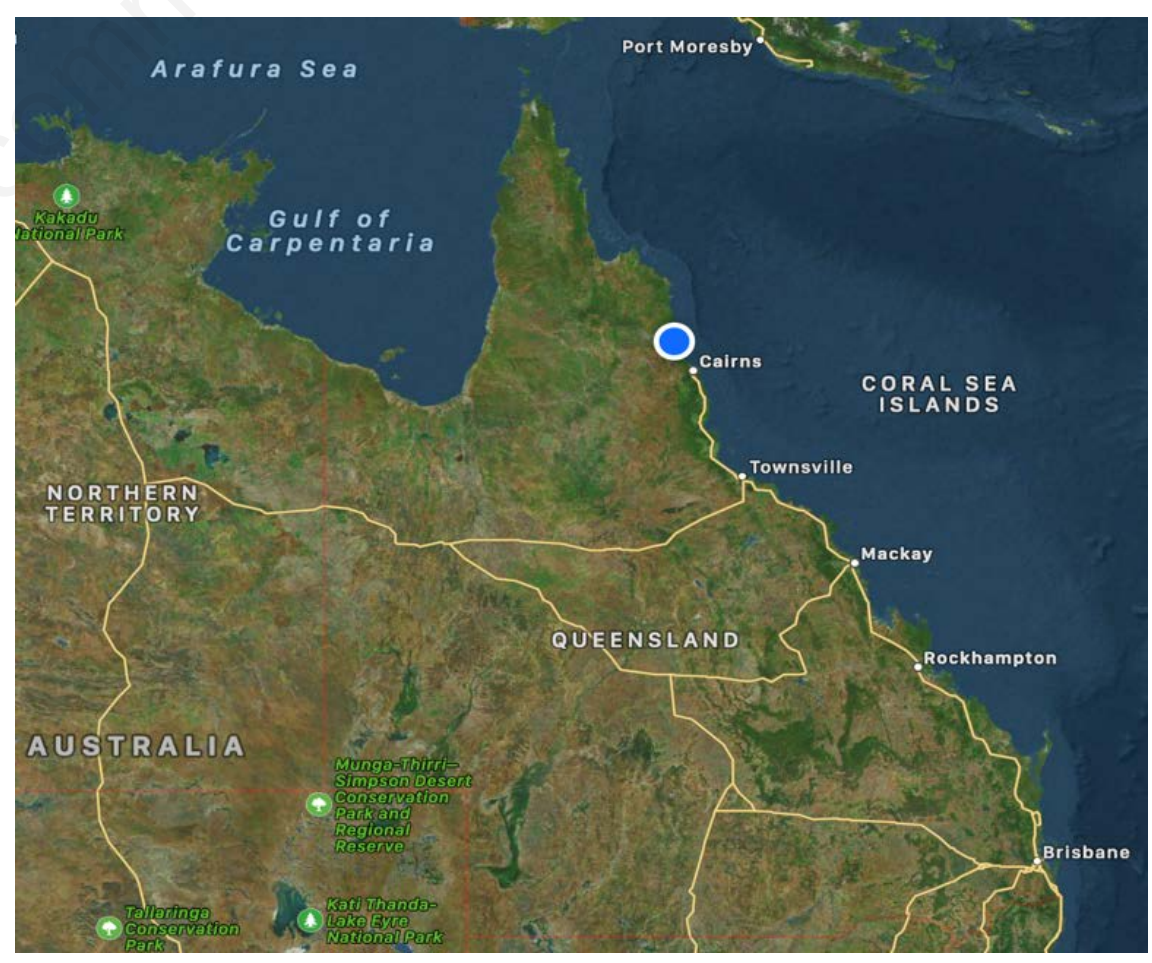

Figure 1. A map of Queensland. The blue dot is the field research area in the vicinity of Wonga Beach (16.35 S). Courtesy Apple Maps.
Lewis Bernays, one of the founders and

tree of about fourteen feet in height, but without fruit."12 Banfield, in Confessions of a Beachcomber, wrote that the traditional owners climbed the tree to harvest the coconuts and that it was cut down by a ers killed him because they were angry about losing their valuable tree. ${ }^{23}$ This adds weight to the body of evidence that traditional owners valued the coconut palms they owned as recorded by Hynes and Chase, the Hershbergers and Tucker.

\section{Coconut classification}

The classification of coconut phenotypes is complex and evolving as more research gets published. A simple analysis is sufficient for this article. Coconuts are diviinto Indo-Pacific and Indo-Atlantic morphological characteristics - niu kafa and niu vai. ${ }^{6}$ Niu kafa are oval, three-sided wild-types with thick husks and small kernels. Niu vai are large round, cultivated types with thin husks and large kernels. ${ }^{24}$ wo main 
Presidents of the Queensland Acclimatisation Society wrote in 1883 that they imported nuts from a plantation in Singapore. Bernays described the importation: "...the entire batch were incomparably superior in size to the fruit commonly imported from the islands of the Pacific."14

The nuts from the Singapore importation were planted in Mackay in the 1870 s and started to bear fruit by 1883 . The largest nuts from these nursery trees were used as the basis for the introduction of coconuts in Queensland.

According to Bernays: "The nuts for sowing should be selected from a vigorous tree and a good producer, and should be large, ripe, sound, dark-coloured, and spherical, with little husk. Avoid long and pointed nuts, as they produce more husk than kernel." 14

This clearly shows that they selected niu vai over niu kafa, even though the naming of the two phenotypes did not occur until nearly a century later. ${ }^{24}$ The nuts that were selected were large and spherical due to the superior levels of kernel recovery for copra and oil production.

It is clear that they avoided selecting and planting niu kafa and their intermediate phenotypes. This is strong evidence that these phenotypes were not introduced, and these self-sown palms are therefore native to Australia.

Small numbers of the best niu vai nuts from the nursery trees were sent to various locations in tropical Queensland in the 1880s. The main program started in 1892 and finished in 1900 when the government commissioned the cutter, Lizzie Jardine, to plant thousands of coconuts, sourced from the Mackay nursery, on the islands of the Great Barrier Reef. The aim was create a commercial copra industry with a secondary aim of providing a food source for shipwrecked sailors. ${ }^{25,26}$

The Annual Report for Queensland Department of Agriculture for the Year 1894-1895 and other reports show that many of them did not survive as they were not adequately maintained due to a lack of knowledge. ${ }^{25,26}$ Young coconut palms need regular watering until they establish deep roots to access the fresh water table. ${ }^{2}$ Many died from drought in the dry seasons especially in the central sections of the Great Barrier Reef. They were watered with sea water under the misunderstanding they need saltwater, killing many. All palms on some islands were burnt out and eaten by traditional owners and bêche-de-mer fishers. Palms were consumed by herds of feral goats that defoliated vegetation. ${ }^{25,26}$ Under to today's accountability standards the introduction would be seen as a misman- aged disaster. Small mission plantations such as Palm Island, Bloomfield, McIvor River, Hopevale and Mapoon faired better. There were several larger plantations such as at Somerset, Wonga Beach and Bramston Beach that started after 1900. The copra industry ended by the late 1920s because the cost of labour in Australia was uncompetitive compared to the plantations in Asia and the Pacific. ${ }^{2,25}$ The plantations do not exist today. However, there is a widespread belief that all the coconuts in Queensland have come from this introduction period.

\section{Field research in the vicinity of Wonga Beach}

Wonga Beach (16.35 S) was chosen for field research as it was the site of a commercial plantation. The aim was to examine nuts and palms to understand if all selfsown coconuts on the littoral foreshore in that region were descended from the introduced large round niu vai phenotype, to test the belief that all coconut palms in Queensland were introduced.

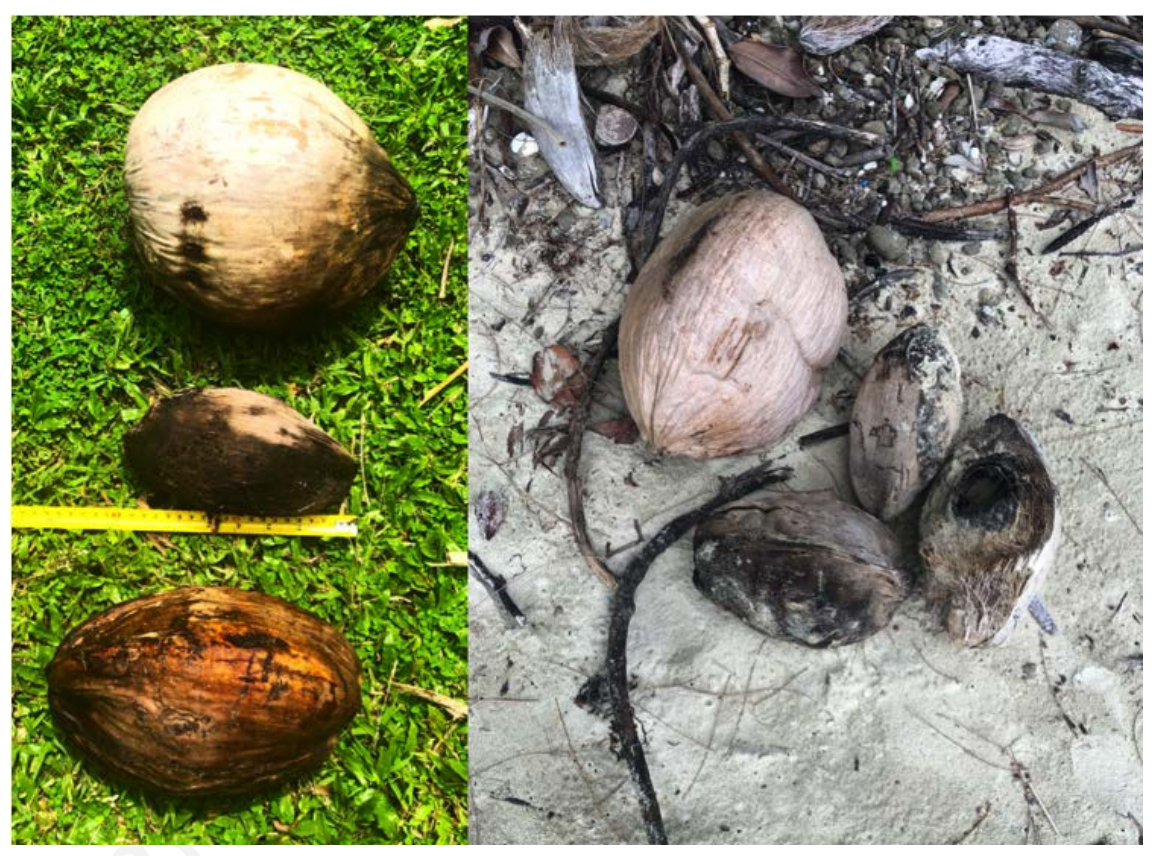

Figure 2. Top Left: A niu vai coconut that is a descendant of the commercial plantation at Wonga Beach. Bottom Left: A nut from a self-sown niu kafa palm found at Rocky Point. Middle Left: a very small wild-type drift nut found on the strand line at Four Mile Beach, Port Douglas. It can also be seen in the picture on the right side. It is a viable nut that is starting to sprout. The coconuts on the right side are drift nuts found on the stand line on Fourmile Beach. There is a niu vai, two small niu kafa nuts and the very small wild-type nut.

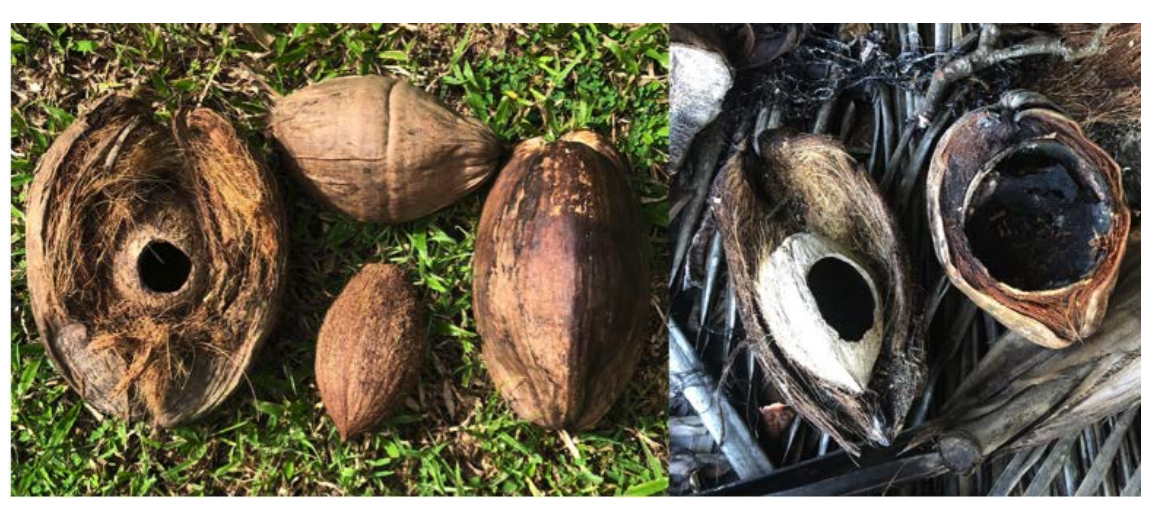

Figure 3. Left: The thick husk and small round kernel of a niu kafa. Middle: a unique small, elongated kernel that comes from the self-sown niu kafa on the right. Top: Small nut that grows on tall trees. Far Right: An elongated niu kafa compared to a small niu vai intermediate type on Four Mile Beach. 
Many of the coconuts palms on the beach foreshore adjacent to the old plantation have large spherical niu vai nuts or intermediate forms that are either elongated or smaller in size. Only a few kilometres away at Rocky Point, there is a diversity of palm and nut types including niu vai, niu kafa, small and intermediate forms on the littoral foreshore as shown in Figures 2-4. The same diversity can be found 15 kilometers away by sea, on the littoral foreshore of Four Mile Beach at Port Douglas. Figure 3 shows different forms of niu kafa kernels including a unique elongated kernel and an example of very small nuts that grow on tall trees. The crown shapes of the niu kafa palms can be clearly distinguished from the niu vai as shown in Figures 4 and 5 . Niu kafa, smaller and intermediate types were not introduced for copra production.

\section{Discussion}

The large round niu vai phenotype is not the dominant self-sown coconut on the littoral foreshores of Rocky Point and Four Mile beach, even 100 years after it was introduced at Wonga Beach. There is wide variety of nuts including different forms of niu kafa, very small nuts that could be wildtype ancestors, half sized niu vai and numerous intermediate forms. These nuts have no commercial value and were not introduced for copra production in the 1890 's government program. They should be regarded as native Australian phenotypes.

Niu kafa was already in Queensland prior to European colonization. The record of the nuts from the tree found at Carrawal are clearly niu kafa. ${ }^{3}$ The shape of the crowns of the Russell Island palms in the picture drawn by Brierly in 1848, show a niu kafa form. ${ }^{1}$

Niu vai were developed in Asia through thousands of years of human selection of improved niu kafa varieties, independently, at least 4 times. ${ }^{6}$ They were taken by Melanesian, Polynesian and Micronesian seafarers, along with other domestic plants and animals such as bananas, breadfruit, taro, chickens and pigs on their migrations as they colonized the Pacific, thousands of years ago. The paleo-archeological records show increases in coconut pollen on islands with the arrival of these cultures due to the cultivation of coconuts. The cultivated niu vai hybridized with the wild type niu kafa, which pollen records show had drifted their thousands of years earlier, creating intermediate types. Niu vai and intermediate types would have regularly drifted to Australia for thousands of years and self-sown. ${ }^{6,24}$ They only had to drift around 60 kilometers from the Torres Strait Islands. ${ }^{5}$

The introduced, large spherical niu vai nuts came from the first commercial plantations developed by colonist in Asia in the $1840 \mathrm{~s}^{24}$ They selected the largest nuts to achieve the highest levels of copra produc- tion per hectare. This is a cultivated phenotype that has been spread by people rather than a self-sowing wild type. Consequently, they are not as adept at self-sowing as niu kafa and intermediate types that have thicker husks and are more buoyant. ${ }^{3,24}$ This is the reason why, after more than 100 years,

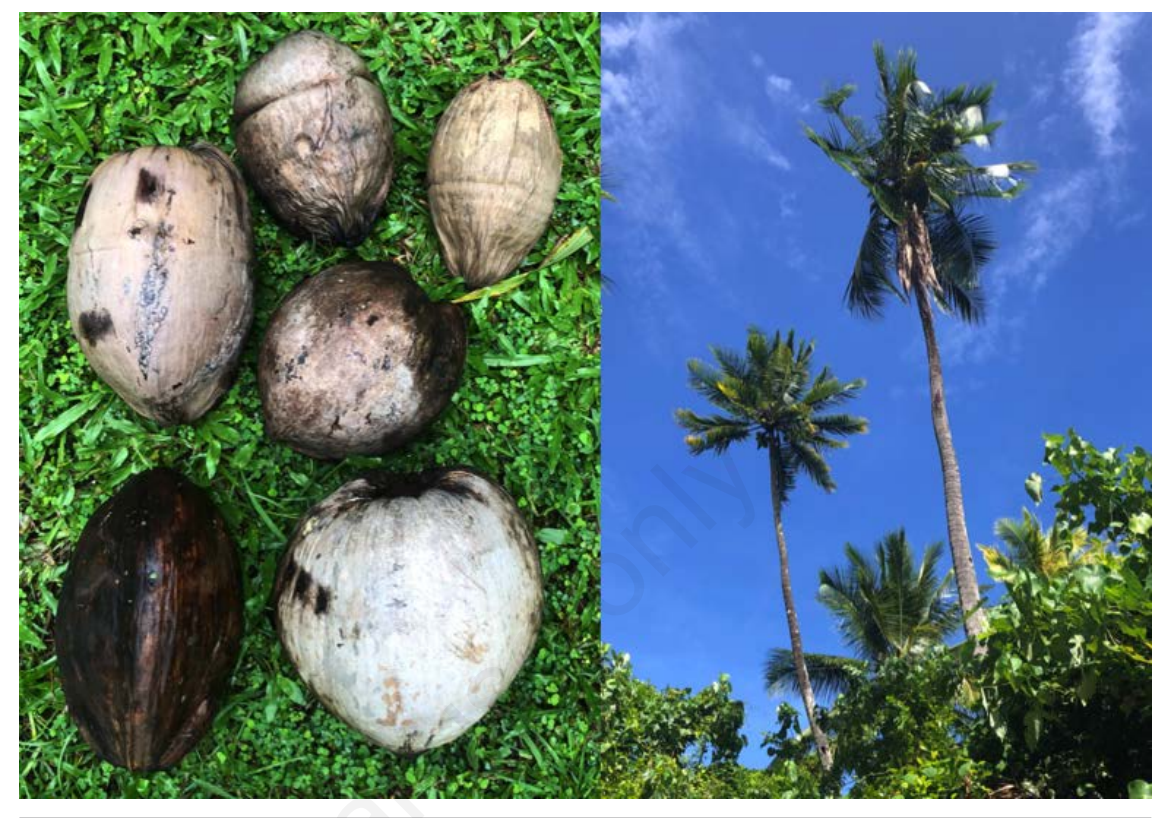

Figure 4. Left Side: Examples of nuts found in the Wonga Beach region. Bottom Left is a niu kafa. Bottom Right is a niu vai. The nuts in the middle are examples of intermediate forms. The nuts at the top of the picture are small nuts that grow on tall trees that may be examples of ancestral wild-type coconuts. Apart from the large round niu vai, these types of nuts were not introduced for copra production and are examples of native Australian phenotypes. Right side: Self-sown palms on the littoral edge, at Rocky Point. The palm in the front center is a wild-type niu kafa, the palm on the left is a niu kafa intermediate-type. The palm with the larger fronds in the middle is a niu vai. The niu vai clearly has larger fronds and a fuller crown than the other palms in the picture, even though it is further back.

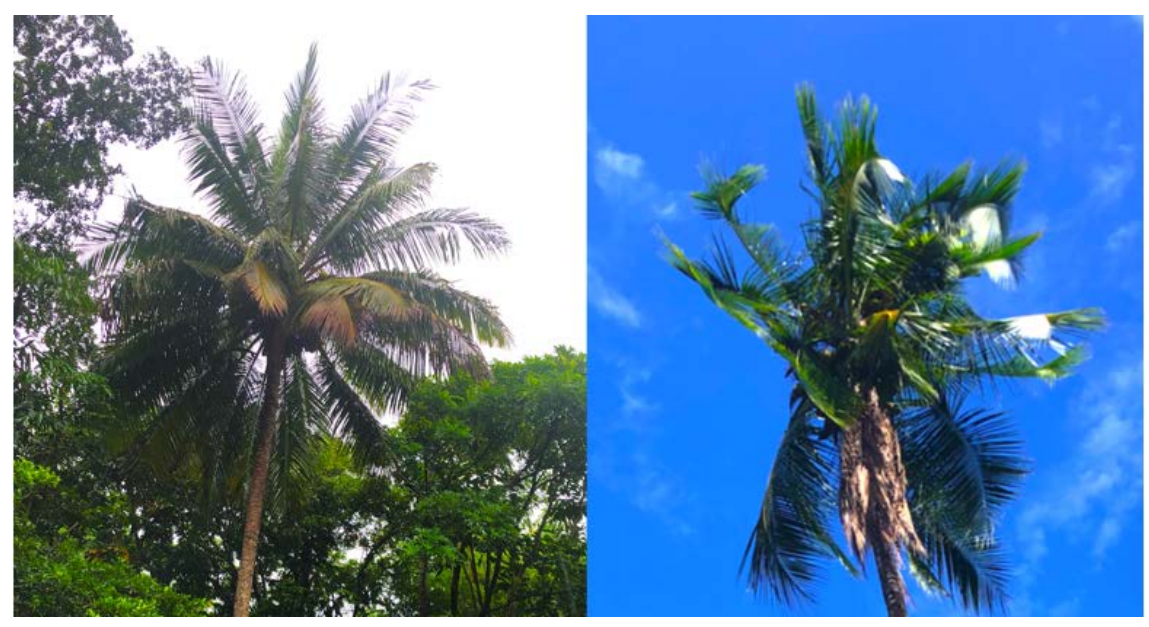

Figure 5. Left: The full dense circular crown of a niu vai. Right. The semi-upright form of the crown of a self-sown niu kafa. It does not have the full dense circular crown and tends to have a more upright crown shape, has fewer fronds and they are smaller in size than niu vai. Intermediate types have a diversity of crown shapes that range from the wild-type niu kafa to the niu vai forms. 
they are not the dominant phenotype on the littoral foreshore of tropical Queensland.

I have been researching coconuts since 1971 in Australia and globally. From my experience the majority of self-sown coconut palms growing on the littoral foreshores in Australia do not have the large spherical form of the introduced niu vai pictured in Figures 2 and 4. Some niu kafa intermediate varieties are a result of the natural changes that eventually led to niu vai. They are not hybrids. Some intermediate varieties are the result of cross pollination between niu vai and niu kafa. ${ }^{6,24}$ Most of these hybrids in Queensland would have native Australian niu kafa parentage. Most self-sown coconut palms growing along the littoral edge are intermediate forms, such as those shown in Figure 4. It is reasonable to assume that they have genetics of native Australian origin.

A comprehensive Whole-Genome Sequencing needs to be done on Australian coconuts and compared with Asian, Indian Ocean and Pacific phenotypes to fully clarify the diversity of Australian coconuts and their relationships with other nuts in the Indo-Pacific. There is an urgent need to collect and document coconuts to establish cladograms to understand the phylogenic relationships of these different phenotypes.

\section{Conclusions}

The evidence that coconuts were growing on the Australian mainland prior to European colonization in 1788 is compelling. Australia has a diversity of coconut phenotypes, many of which are unique. The large round niu vai phenotype that was introduced into Queensland in the 1870 s is not the dominant self-sown coconut. The majority of self-sown coconuts are intermediate forms that would have Australian genetics and are therefore native. The current culling programs could be resulting in the extinction of unique Australian coconuts, including the original wild-type ancestors of the current coconuts. The destruction of coconuts is based on the poorly researched belief that they were not in Australia before the arrival of European colonists, they have been introduced and therefore invasive weeds. ${ }^{4}$ The Russell Island groves no longer exist. We have lost these unique native Australian coconuts forever. They are extinct.

The unique Australian phenotypes must be documented and preserved in situ in their natural ecosystem: the beach edge of littoral forests. The first part of this process is to stop the destruction of coconuts to prevent the further extinction of unique Australian biodiversity.

\section{References}

1. Dowe J, Smith L. A brief history of the coconut palm in Australia. Palms 2002;46:134-8.

2. Foale M. The coconut odyssey: the bounteous possibilities of the tree of life. ACIAR Monograph No. 101, 132 p. 2003.

3. Buckley R, Harries H. Self-Sown WildType Coconuts From Australia, Biotropica Vol. 16, No. 2 (Jun., 1984), pp. 148-151 Published by: Association for Tropical Biology and Conservation DOI: $10.2307 / 2387847$ https://www.jstor.org/stable/2387847

4. Lowe T. It's time to stop promoting coconut palms as symbols of tropical Queensland, Australian Geographic, 2016. Available from: https://www. australiangeographic.com.au/topics/wil dlife/2016/12/coconut-palms-shouldntbe-promoted-as-symbols-of-tropicalqueensland/ (accessed April 13, 2021)

5. Leu A. The evidence for native coconuts growing in Australia. Int J Plant Biol 2021;12:9025 .

6. Gunn BF, Baudouin L, Olsen KM. Independent origins of cultivated coconut (Cocos nucifera L.) in the Old World Tropics. PLoS one 2011;6:e21143.

7. Rigby JF. A fossil Cocos nucifera L. fruit from the late Pliocene of Queensland, Australia. Birbal Sahni Centenary Vol. pp 379.381, 1995.

8. Dowe J. Australian Palms: Biogeography, Ecology and Systematics, CSIRO Publishing, Collingwood, Vic, Australia, 2010.

9. Lee I. Early Explorers in Australia, From the Log-Books and Journals, Methuen \& Co., London, 1925.

10. King P. Narrative of a survey of the intertropical and western coasts of Australia. Performed between the years 1818 and 1822; with an appendix containing various subjects relating to hydrography and natural history, Volume 1, Murray, 1827.

11. Dalrymple G. Narrative and reports of the Queensland North East Coast Expedition 1873. Queensland Government Printer, 1874.
12. Jukes J. Narrative of the Surveying Voyage of HMS Fly: During the Years 1842-1846, Volume 1, T\&W Boone, London, 1847.

13. Queensland Acclimatisation Society. The Minutes of the November 2, 1869 meeting, Queenslander, Brisbane, Saturday, 27 November 1869.

14. Bernays LA. Cultural Industries for Queensland, James C. Beal, Government Printer, Brisbane, Queensland, 1883.

15. Thozet A. Letter to the editor published in The Sydney Morning Herald, Wed 6 January, 1869.

16. Mueller F von. Fragmenta Phytographiae Australiae, Volume 5, Government of Victoria, Melbourne, 1865-66.

17. Flood J. The Original Australians - The Story of the Aboriginal People. Allen \& Unwin, 2nd Ed, 2019, pp 32-33.

18. Bligh W. A Voyage to the South Sea, George Nicol, Pall Mall London, 1792.

19. Hynes R, Chase D. Plants, Sites and Domiculture: Aboriginal Influence upon Plant Communities in Cape York Peninsula. Archeology in Oceania, 1982; Volume 17, Issue 1.

20. Tucker R. Palms of Subequatorial Queensland, Palm and Cycad Societies of Australia (PACSOA). 1988. Available from: http://www.pacsoa.org.au/palms/Cocos/ nucifera_oz.html

21. Hershberger H, Hershberger R. Kuku Yalanji Dictionary 1982, Reprinted 1998. Available from: http://www.ausil.org.au/sites/ausil/files/ WP-B-7\%20English\%20-\%20KukuYal\%20Dict._0.pdf

22. Neame A. Memoirs of Arthur Neame, Queensland Heritage, v1 no4 p26 32.pdf, 1966.

23. Banfield EJ. Confessions of a Beachcomber, Dixon Price Publishing, February 15, 2001.

24. Harries HC. The evolution, dissemination and classification of Cocos nucifera L. Botan Rev 1978;44:265-319.

25. Daley B. Changes in the Great Barrier Reef since European settlement: implications for contemporary management. $\mathrm{PhD}$ thesis, James Cook University. 2005. Available from: https://researchonline.jcu.edu.au/1312/ Accessed Feb 28, 2021

26. Annual Report for Queensland Department of Agriculture for the Year 1894-1895, Queensland Government, 1895. 